\title{
OS ESPAÇOS DA FÉ: UM ESTUDO SOBRE O CAMPO RELIGIOSO NA PERSPECTIVA DA RELIOSIDADE POPULAR $^{1}$
}

\author{
André Camargo Lopes ${ }^{2}$
}

\begin{abstract}
Resumo
Tendo em vista as constantes transformações do campo religioso brasileiro, o presente artigo, procura analisar, a partir de entrevistas e observações de campo, a manutenção e a prática ritualística dos dois grandes grupos religiosos que compõem o cotidiano social de um bairro popular de pequeno porte do município de Londrina-PR. São discutidas a circularidade entre o discurso oficial e a prática religiosa dos agentes, a manutenção do catolicismo tradicional popular, assim como a observação de um culto, e a análise dos elementos constitutivo da identidade assembleiana no bairro.

Palavras-chave: Religiosidade. Representações. Identidade.
\end{abstract}

\footnotetext{
${ }^{1}$ Este artigo é parte integrante da monografia apresentada ao Curso de Especialização em Ensino de Sociologia, sob orientação da Prof ${ }^{a}$. Dr ${ }^{a}$. Maria José de Rezende. Sou grato à Prof ${ }^{a}$. Dr ${ }^{a}$. Martha Ramírez-Gálvez pela leitura atenta e pelo trabalho de revisão.

${ }^{2}$ Professor da Rede Pública de Ensino do Estado do Paraná, graduado em Artes Visuais (2002) e especialista em Ensino de Sociologia (2007) pela Universidade Estadual de Londrina. Atualmente é mestrando em História Social nesta instituição.
} 


\begin{abstract}
In view of the continuous change in the Brazilian religious field, this article is aimed at analyzing, through interviews and field observation, the maintenance and the ritual practices of the two major religious groups in the daily life of a small popular neighborhood in Londrina, state of Paraná. The discussion includes the circularities between the official discourse and the practices of religious agents, the maintenance of traditional popular Catholicism, the observation of a regular worship service, and an analysis of the elements that constitute the neighborhood's religious identity of the Assembléia.
\end{abstract}

Keywords: Religiosity. Representations. Identity.

Ao longo deste artigo, abordaremos o elemento cultural-religioso como um definidor de padrões comuns, determinante na formação e segmentação de grupos sociais que se distinguem nas múltiplas representações do universo religioso que compõem o cotidiano em um bairro popular no Município de Londrina (Paraná). Procuramos identificar, entre os moradores, a construção e a manutenção de suas identidades religiosas, tanto no espaço doméstico quanto em suas "comunidades". Neste sentido, procuramos estabelecer relações sociológicas entre as práticas religiosas e a construção das representações cotidianas do universo funcional desses agentes. Para tal efeito, centramos nossas observações nos depoimentos gravados e nos levantamentos realizados junto aos moradores do bairro, procurando promover um diálogo entre as suas representações e as transformações correntes no campo religioso, a partir do cotidiano de vivência dos próprios agentes.

Nesta perspectiva, ao se construir um quadro teórico para a análise da construção do sentido religioso nas camadas populares este só pode ser apreendido junto ao entendimento das relações estratificadoras do campo cultural e na relação interpenetrativa de seus estratos. Ou seja, na relação entre os agentes sociais e as instituições religiosas mediadas pelas ramificações culturais e veiculadoras de seus discursos.

0 popular tem seu sentido atrelado aos espaços sociais onde seus agentes estão inseridos. Tal como afirma Vovelle (1985), ao nos depararmos com a religião popular, estamos lidando com um universo cultural dinâmico, por esta não se encontrar desvencilhada de outras práticas culturais, naquelas em que as práticas culturais e religiosas locais influenciam e são influenciadas pela religião 
ensinada. Neste sentido, a definição de "popular", encontra-se dentro de um campo de oposições e relações (CESAR, 1976: p. 6), revelador um dinamismo que pode ser compreendido a partir de uma abordagem dialética entre as instituições e os indivíduos que se relacionam no cotidiano dinâmico que estrutura o universo cultural.

A religião popular enquanto prática social, não deve ser entendida como “(...) um conjunto pitoresco e de crendices e práticas mágico-religiosas, mas ao contrário, constitui um sistema coerente e complexo de crenças e práticas do sagrado, combinadas com agentes e trocas de serviços" (BRANDÃo, 1985, p. 32). Ela não é uma criação religiosa exclusiva e isolada dentro do imaginário religioso dos setores populares, mas sim, retraduz para dentro desses setores o conhecimento e a prática erudita da religião dominante, a partir de uma relação com o universo social e simbólico destes.

De acordo com Chartier (1995), o "popular" qualifica um tipo de relação, um modo de utilizar objetos ou normas que circulam na sociedade, mas que apresentam inúmeras maneiras de receber, compreender e manipular esses elementos. Ou seja, o popular como qualificador de um sistema de relações sociais intimamente ligados à ação cotidiana, remetendo-se aos seus respectivos produtores, relacionando-os ao seu tempo social e espaço social.

\section{Alguns apontamentos SOBRE o CAMPo RELIGIOSO}

Ao pensarmos o campo da religião, devemos ter em mente que este é definido, como uma relação interior com a realidade transcendente, a partir de uma experiência com o sagrado vivida interiormente, ou seja, a religião se estrutura dentro das múltiplas dimensões pessoais que compõem o espaço da coletividade. Para os fenomenólogos da religião, o homem é "naturaliter religiosus", sendo esta característica um elemento constante nos seres humanos em todas as épocas. Neste sentido, como afirma Martelli (1995), o sagrado é entendido como o reconhecimento a apelo a seres superiores e transcendentes, ou seja, a experiência religiosa consiste em experimentar a presença do sagrado. Segundo o autor, em todas as religiões podem ser individuados dois significados principais do sagrado: aquilo que dá a salvação porqueépoderoso (potencialidade) e aquilo queéseparado do profano (sanctus). É a partir destes dois elementos juntos, que Martelli (1995), define uma descrição da experiência religiosa na ordem do vivido. 
0 estudioso da religião Rudolf 0 tto ${ }^{3}$, afirma que a religião não consiste somente nas suas expressões racionais, mas sim, numa experiência direta do indivíduo com o sagrado, o que para o autor, a essência de qualquer religião é a experiência que os agentes que a compõem mantêm com uma realidade outra, que se manifesta no plano da consciência (uma predisposição a priori) destes, antes mesmo de ser incorporada nos ritos e mitos, e preservadas por um grupo de especialistas 4 .

$\mathrm{Na}$ concepção do autor, o neologismo numinoso, pode ser entendido como um princípio ativo presente em todas as religiões, portador da idéia de bem absoluto. É a partir dessa relação que Otto promove a categorização do sagrado enquanto uma experiência vivencial dos próprios agentes religiosos, revelando, em sua categorização, os três elementos que possibilitam uma apreensão desta relação dos agentes religiosos com o sagrado: o mysterium tremendum et fascinans 5 .

Nesta perspectiva da religião como uma experiência que transcende as relações naturais, o historiador das religiões Mircea Eliade (2001), remete esta experiência à ordem das manifestações, num processo de racionalização do homem religioso no qual o sagrado se projeta nos objetos, fenômenos naturais e no espaço. Esta realidade manifestada (hierofania) coloca em oposição os limites

\footnotetext{
${ }^{3}$ Segundo Martelli, Otto em sua célebre obra 0 Sagrado (1917), fundador da fenomenologia abrangente, afirma que o divino não é somente espírito, razão, vontade onipotência, bondade, imensidade, etc. no divino há um aspecto inefável, percebido pelo sentimento como realidade sagrada; esta constitui o fundamento meta-racional da própria Religião (p. 140).

${ }^{4}$ A categoria fundamental de que parte Otto é a de numinoso. 0 termo é pouco usual, mas se revelou muito expressivo. Provém da palavra latina numine que significa divindade. 0 sufixo oso corresponde a cheio de (medroso = cheio de modo; numinoso = cheio de divindade). Rudolf Otto quer apreender o racional e 0 irracional na idéia de Deus, para o que procede a analises histórica, psicológica e semântica do conceito de numinoso. Tratando-se de um a priori não pode ser definido, mas pode ser descrito. Ao proceder a tais descrições, louva-se ao que lhe parece seja a função das experiências do temor, da fascinação e do aniquilamento (PAIM, 1997, p. 11).
}

\footnotetext{
${ }^{5}$ Estas três características são assim definidas por Otto: o numinoso é mysterium, por que só pode ser captado pelo sentimento religioso e não pela razão; o numinoso é um mistério tremendum, enquanto suscita no crente um snetimento de tremor, temor , o que se encontra na base dos conceitos morais da justiça divina; o numinoso não é somente um mistério terrível, mas também é fascinans, ou seja, é um impulso substancial de um Bem que só a experiência religiosa conhece, por ser praticamente irracional, e os conceitos racionais que se manifestam a partir deste aspecto do numinoso é o amor, a misericórdia, a piedade, o conforto. Toda esta categorização do numinoso é um processo de moralização racionalizadora da experiência religiosa que 0 autor diz estar compreendido numa perspectiva da Teologia das religiões (MARTELLI, 1995, p. 141-142).
} 
do humano e do sagrado no corpo de um mesmo objeto ou em um mesmo espaço, pois de acordo com o próprio Eliade, a experiência do sagrado é um elemento na estrutura da consciência do homem, uma valoração simbólica desses elementos que não descaracteriza o objeto em sua essência.

Ainda na ordem das manifestações, para o homem religioso, o espaço não é homogêneo, o espaço apresenta rupturas, há porções de espaços qualitativamente diferentes das outras. Há, portanto, um espaço sagrado, significativo, mas há, também, outros espaços não-sagrados. 0 espaço sagrado, tal como aponta Eliade, é ruptura deste com a totalidade do espaço, são áreas diferenciadas, criadas pela própria intenção do agente, é o centro do mundo.

Outro elemento significativo na constituição da experiência do sagrado dentro do pensamento de Eliade está associado à temporalidade. Para o autor, tal como o espaço, o tempo não é para o homem religioso, nem homogêneo e nem contínuo. Há, portanto os intervalos do tempo sagrado, o tempo da festa (na sua grande maioria, festas periódicas) por outro lado, há o tempo profano. Nesta perspectiva, Eliade afirma que o tempo do homem religioso é fragmentado em dois estratos, dos quais o mais importante, o tempo sagrado, se apresenta sob um aspecto paradoxal, de um tempo circular, reversível e recuperável, uma espécie de eterno presente mítico, que o homem reintegra periodicamente pela linguagem dos ritos.

Eliade nos remete a uma observação dos universos mentais que coletivizam e fundamentam a experiência religiosa em seus mitos e rituais. Assim, independentemente do contexto histórico, o homo religiosus, atribui à sua existência material, uma realidade absoluta, o sagrado, transcendendo o mundo de suas relações materiais à medida que se manifesta neste, santificado e tornado real.

Neste sentido, compreender a constituição do campo da religião evoca 0 conhecimento do processo de legitimação e sistematização do sagrado a partir de perspectivas que se estruturam dentro do campo social: o da religião como uma instituição social que exerce uma coerção sobre os agentes sociais acerca de sua representação coletiva de mundo; e o da religião como uma prática social, levando em consideração a ação de seus agentes sociais na integração e constituição da legitimidade do campo. Para tal, a sociologia clássica, de Durkheim e Weber, nos oferece as ferramentas necessárias para identificar nas relações sociais, a ação da sociedade sobre os agentes na constituição de uma representação coletiva, e 
os influxos inovadores dentro deste campo religioso. Em ambas as concepções, dentro de suas particularidades apreensivas do fenômeno religioso, são acentuados no campo das relações sociais o estabelecimento da organização, produção e apreensão moral de uma experiência sócio-religiosa, como princípio ativo da experiência coletiva.

Para Durkheim (1988), a religião é um produto eminentemente social, sendo as representações religiosas, representações coletivas ${ }^{6}$. Neste sentido, as categorias religiosas refletem o sistema social, o pensamento coletivo. Sendo estas categorias, representações coletivas, Durkheim aponta para uma origem social, de toda a forma e manifestação do pensamento religioso.

Na lógica durkheimiana, as representações coletivas que fundamentam as representações religiosas do grupo social são produtos de uma imensa cooperação que se estende não apenas no espaço, mas também no tempo. Nesta perspectiva, a religião origina-se da efervescência coletiva de um grupo social, na que a concentração (no caso do rito) deste, possibilitada por meio da experiência com o sagrado, vem a reforçar a totalidade social, identificando, nesta órbita, o social com o moral e com o religioso. Pois o sagrado é representado em símbolos, crenças e práticas religiosas, as quais contribuem para alimentar e reforçar o próprio sentimento religioso ${ }^{7}$.

Nestesentido,ocampo da religião, comoumainstituiçãosocial gerenciadora dos sentidos da fé, contribui para a imposição de princípios de estruturação da percepção e do pensamento do mundo social, por meio de um sistema de práticas e representações acerca do natural-sobrenatural reproduzidas e traduzidas pela tradição.

A presença do sagrado como a manifestação ideal, que materializa, em seus símbolos, as aspirações do grupo social, revelando em seu corpo religioso

\footnotetext{
${ }^{6}$ Segundo Durkheim, representações coletivas são conceitos comuns a todo 0 grupo social que 0 envolve, sendo um elemento comunicativo pelo qual as inteligências humanas se comunicam. Neste sentido as representações coletivas se caracterizam por sua objetividade, legitimada e controlada pela experiência dos agentes sociais pertencentes ao grupo (DURKHEIM, 1988, p. 175182).

${ }^{7}$ De acordo com Martelli, a diferença radical entre Durkheim e os fenomenólogos é sobre a tese sociogenética, pois Durkheim encontra o momento genético da religião nos estágios de efervescência coletiva, enquanto que para os fenomenólogos, porém, o ritual e a dimensão social não são a causa, mas apenas a ocasião para a manifestação de uma presença e um poder que transcendem a realidade humana (MARTELLI, 1995, p. 159).
} 
uma conduta moral, aparece em Weber (1999), sob a lógica de dois prismas: tanto o de reforço e justificação dos ordenamentos sociais existentes, como de crítica e subversão destes últimos. Esta postura contraria a tese durkheimiana, mas não a desqualifica, tendo em vista que a prática religiosa concentra em si a organização ética que afeta a estrutura social tanto na singularidade de seus indivíduos, quanto na postura social do grupo abrangido pela ética racionalizadora e emanada pelo desejo coletivo. Neste sentido, a religião é vislumbrada a partir da ação de seus agentes estruturadores, e não apenas como um campo de reprodução da ordem social, uma consequiência histórica. A teoria weberiana atribui a este campo a dinamicidade dos influxos históricos da mudança social.

A partir da teoria acerca do carisma, Weber demonstra que as religiões universais se originam da pregação de um profeta, ou de uma figura carismática, isto é, uma pessoa dotada do dom da graça, a redor do qual se reúnem os discípulos.

Outra característica do carisma é o seu caráter irracional, ou seja, a falta de regras e 0 alheamento a considerações econômicas. Por ser personalista, o carisma, enquanto reconhecimento social exige, de seu portador, provas constantes de sua qualidade excepcional. Com a morte do carismático, tende-se a um movimento de institucionalização do carisma, tornando-se um possível objeto de educação e aquisição dos valores socialmente compartilhados, contribuindo para a formação de uma comunidade estável e organizada, por meio de um processo de racionalização da gestão do carisma na vida cotidiana da comunidade.

Neste sentido, os discípulos institucionalizam o carisma, isto é, criam um corpo doutrinal, práticas cultuais e uma organização sacerdotal que constituem outros tantos suportes para poder reviver, na vida cotidiana, a experiência religiosa do fundador. 0 pragmatismo racional da salvação atua, segundo Weber (1999), a partir da índole estruturante das concepções de "Deus", refletindo em sua elaboração uma adequação prática de vida.

Bourdieu (2005), contribui para esta compreensão weberiana da religião, ao problematizar suas discussões acerca do campo religioso ${ }^{8}$, por meio

\footnotetext{
${ }^{8}$ Estamos trabalhando a religião na perspectiva de um campo social delimitado pelas ações legitimadoras de seus agentes; para isso, estamos fazendo uso do conceito de campo social de Pierre Bourdieu. De acordo com o autor, os campos sociais são espaços estruturados de posições, em que a estrutura do campo é um estado de relação de força entre os agentes e as instituições engajadas na luta (política, família, religião, núcleos acadêmicos etc.), naquela em que estes agentes lutam por legitimidade de suas ações, a partir de um número de interesses em comum acerca do campo, daí

OS ESPAÇOS DA FÉ: UM ESTUDO SOBRE O CAMPO RELIGIOSO ... 
da monopolização dos bens de salvação. De acordo com o autor, ao se pensar o campo religioso, deve-se pensar o sistema de relações sociais que o legitima: o corpo de especialistas religiosos. Bourdieu aponta ainda que este processo de legitimação e centralização do campo religioso promove um movimento no sentido contrário em relação aos grupos excluídos deste campo. Para o autor, ocorre uma desapropriação objetiva daqueles que são excluídos e que se transformam, por esta razão, em leigos, destituídos do capital religioso enquanto trabalho simbólico acumulado.

Este movimento de legitimação e centralização que estratifica a oposição entre os detentores do monopólio da gestão do sagrado e dos leigos, constitui a base para uma abordagem do campo religioso em uma perspectiva dicotômica entre a religião enquanto uma instituição social, e a apropriação do sentido do sagrado na religiosidade popular.

A prática do poder simbólico se reforça dentro do campo da religião pela apropriação dos símbolos. Baczko (1985), acerca desta prática de manipulação sobre a construção de um imaginário social, aponta que a legitimação e 0 controle das representações sociais se dão a partir de um controle dos discursos e dos símbolos que centralizam e monopolizam as forças reguladoras da vida social. Logo, esta centralização dos bens simbólicos que ordenam o campo religioso, estrutura as relações dos agentes por meio de um controle da vida coletiva. Neste sentido, a concorrência pelo poder religioso, reside seu alvo no monopólio do exercício legitimo do poder (BOURDIEU, 2005), e na prática e visão de mundo dos leigos, impondo-lhes um habitus religioso.

0 campo religioso tem por função especifica satisfazer um tipo particular de interesse, isto é, o interesse religioso que leva os leigos a esperar certas categorias de agentes que realizem "ações mágicas e religiosas", ações fundamentalmente "mundanas" e práticas, realizadas "a fim de que tudo corra bem para ti que vivas muito tempo na terra" (BOURDIEU, 2005, p. 84).

0 interesse religioso como motivador e resultante deste campo social, coloca em oposição o sentido prático da magia e da religião, tendo como parâmetro delimitador o próprio campo social. Os interesses mágicos têm por particularidade aspectos imediatistas e parciais, que se encontram em trânsito em diversos setores sociais, tendo como base cultural um universo meteorológico e animista, estreitamente ligado à natureza.

a cumplicidade objetiva e todos os seus antagonismos (BOURDIEU, 1983, p. 89-94). 
Em contrapartida, as ações religiosas se estruturam em um processo racionalizador e moralizador das necessidades religiosas. Esta ação racionalizadora e moralizante coloca esta ação animista das práticas mágicas em um âmbito opositor, demonizando-as, dessignificando o seu sentido, a partir da ação da experiência religiosa como sentido moralizante da existência.

Na constituição do campo religioso popular brasileiro, este condicionante existencial acaba por ser um elemento determinante nas práticas religiosas de uma legião de fiéis, caracterizando, muitas vezes, religiões domésticas, ministradas pelos próprios praticantes. Souza Barros (1970), afirma que a religiosidade popular e todas as formas decorrentes dessa relação com o sagrado, está associada aos problemas do cotidiano dos agentes sociais, gerenciando muitas vezes todos os atos de suas vidas. Neste sentido, o cotidiano se apresenta como dominado por influências do sobrenatural que se refletem nos atos da vida material.

Nas manifestações religiosas populares, o sacerdote está no meio social dos demais agentes, o que torna o espaço heterogêneo e fragmentado apontando para uma relação multifacetada dos agentes religiosos com o sagrado. Nesta perspectiva, Brandão (1981, p. 141) aponta que dentro das religiões populares, “(...) é a prática religiosa que confere ao crente e ao devoto, vivas, não só as formas pessoais de acesso a fração do mistério, como também a certeza da partilha do poder que sustenta a comunidade que invoca o seu sagrado, com os seus recursos". Ou seja, é a partir de uma relação direta do agente com o sagrado que os agentes sociais em seu momento de fé solidificam suas crenças, compartilhando-as, podendo vivenciá-las de forma ativa.

\section{Perfil Religioso dos moradores do Jardim Paulista}

Ao pensarmos a manifestação das práticas religiosas no bairro a partir de seus agentes, propomo-nos a visualizar a dinamização do fenômeno religioso na construção das identidades e das comunidades religiosas que compartilham, na figurados moradores do bairro, o mesmo espaço de presençasocial. Essasidentidades religiosas não atuam sozinhas enquanto fenômeno social na formação do espaço de sociabilidade. Junto a elas, outros fenômenos sociais também se agregam (condição econômica, nível de formação educacional dos agentes, grupo de orientação sexual etc.) criando o espaço de vizinhança. Todavia, ao longo de nossa pesquisa junto aos agentes do bairro, percebemos que muitos deles estabelecem 0 
seu conjunto de representações sociais tanto domésticas como dentro do espaço social totalizante, a partir de um imaginário que promove a "espiritualização" do sistema de relações materiais da vida social. Ao visualizarmos a constituição desse imaginário, entendemos estes processos como uma construção que está inserida na realidade cotidiana do indivíduo em seu espaço doméstico e social, reforçado por uma rotina de ações concretas e abstratas, que emanam de aspirações, temores, e necessidades imediatas (proteção, objetivos a serem alcançados, curas etc.).

Para uma visualização ampla do espaço religioso, aplicamos, por dois momentos, questionários nas escolas que atendem as famílias da localidade. Procuramos visualizar um padrão no perfil social e sócio-comportamental dessas famílias. Neste levantamento, coletamos informações acerca da estrutura do núcleo familiar (ocupação profissional, composição do núcleo familiar etc.), a composição sócio-religiosa do bairro e de como esta composição influencia as representações dentro do espaço doméstico e social?.

Aplicamos um total de 120 questionários nas escolas, dos quais retornaram apenas 56. Destes, apenas 36 eram de famílias moradoras no bairro Jardim Paulista e na favela Cantinho do Céu, o que já era, para nossos objetivos, um número significativo para um diagnóstico acerca da estrutura social do bairro.

Dentre as 36 famílias moradoras do Jardim Paulista/Cantinho do Céu que retornam o questionário, 13 famílias são evangélicas, 22 são católicas (sendo que destes, 9 não se definiram como pertencente a alguma paróquia) e 1 é adventista. Foi reveladora uma presença significativa de famílias denominadas como "evangélicas" no espaço social do bairro, onde os próprios moradores sentem e apontam esta transformação na constituição religiosa do espaço de vizinhança.

\section{O ESPAÇO SOCIAL EM QUESTÃO}

0 Jardim Paulista é um bairro com pouco mais de cem famílias residentes, incluindo os moradores da favela agregada ao bairro. Às margens da Rodovia Melo Peixoto (Avenida Brasília) que liga o estado do Paraná ao estado de São Paulo, o bairro foi loteado a partir do ano de 1957, é composto por sete ruas.

\footnotetext{
${ }^{9} 0$ total de famílias no bairro (incluindo a favela), não chega a 200 famílias. Em nossa pesquisa, abordamos 63 famílias, residentes em 46 terrenos residenciais, correspondentes a 47,10 \% do total de terrenos residenciais do bairro. Deste total de 192 moradores, tivemos uma divisão populacional de: 39 crianças entre 0 e 14 anos; 23 jovens entre 15 e 24 anos; 29 idosos entre 60 e 84 anos; e 101 moradores entre 25 e 59 anos.
} 
As residências que antes compunham a Rua Brigadeiro Franco (primeira rua do bairro após a Avenida Brasília), atualmente, dividem seu espaço com pátios e barracões de empresas que estão invadindo o espaço habitacional do bairro, promovendo uma reconfiguração do espaço residencial. As ruas Barão de Jaraguá e Zacarias de Góes são as únicas vias de acesso de veículos ao bairro. A primeira é uma via de abertura do bairro para a Avenida Brasília, enquanto que a segunda é uma abertura do bairro para a zona norte do município. A linha de transporte coletivo que atende a região não entra no bairro, sendo que os moradores são recolhidos pelos coletivos nos três pontos de ônibus da Avenida Brasília, ou no ponto da Avenida Lucia Helena Gonçalves Vianna, todos externos ao bairro.

0 isolamento do bairro encontra suas demarcações físicas em três pontos principais: o primeiro na Avenida Brasília, que o isola dos mecanismos de assistência do poder público com suas quatro vias (e nenhuma passarela) margeadas por um grande cinturão de empresas. 0 segundo fator físico de isolamento do bairro é de característica natural. 0 próprio Ribeirão Quati delimita, no bairro, a sua área de extensão e promove a sua invisibilidade com sua densa vegetação que se estende até as margens da Avenida Lucia Helena Gonçalves Vianna. 0 terceiro e último elemento de isolamento do bairro é uma extensa área murada que delimita os espaços do bairro e do antigo Frigorífico São José, que se inicia na Rua Brigadeiro Franco e se estende até o Jardim Santa Mônica, do outro lado do leito do Ribeirão Quati.

Da Rua Brigadeiro Franco até a Rua Nilo Cairo, o que podemos constatar é que estamos diante de um bairro onde a condição de miserabilidade de algumas famílias se esconde no espaço arborizado de suas vias, contrastando com a monumentalidade de algumas edificações construídas nos últimos dez anos. Este bairro se mostra como o espaço onde o poder público municipal tem um alcance mínimo (apenas com uma escola de educação infantil e ensino fundamental), constatação que pudemos comprovar junto aos moradores.

Acerca do corpo humano que compõe o espaço de vizinhança do bairro, em um levantamento pelas ruas, encontramos elementos que demonstram uma renovação das famílias residentes no bairro nos últimos 13 anos. Das suas quatro ruas mais povoadas, a que apresenta um maior número de famílias residindo com mais de 30 anos no espaço é a Rua Brigadeiro Franco, que apresenta um número de 3 famílias habitando há mais de 30 anos na rua, equivalendo a 21,42 \% do número de famílias abordadas na mesma. Superada apenas pela Rua Zacarias 
de Góes, que apresenta um total de 6 famílias, totalizando 50\% das famílias abordadas nesta rua. As ruas que apresentaram um maior número de moradores com menos de 13 anos no bairro, são as ruas Visconde de Guarapuava e Nilo Cairo com 5 famílias cada uma. A Rua Nilo Cairo tem um percentual maior (55,55 \%) em relação ao total de famílias por rua, enquanto a Rua Visconde de Guarapuava comporta 33,33 \% do total de famílias recentes no espaço. Estas características demonstram uma maior renovação de moradores nestas duas ruas, também acompanhada com um maior grau de desemprego e de informalidade entre os moradores em idade entre 25 e 59 anos $^{10}$.

Em relação à renovação dos grupos familiares que compõem o espaço social do bairro, constatamos que, nos últimos 20 anos, 29 famílias se mudaram para o bairro, sendo a Rua Visconde de Guarapuava a que mais recebeu estes novos moradores, num total de 9 famílias, seguida pelas ruas Brigadeiro Franco (7 famílias) e Nilo Cairo (5 famílias).

\section{A CONSTRUÇÃO DE UMA IDENTIDADE RELIGIOSA NAS DUAS FAMÍLIAS CATÓLICAS QUE INICIARAM O PROCESSO DE POVOAMENTO DO BAIRRO}

Ao longo das entrevistas, passado e presente se cruzavam nas representações da vivência religiosa dos moradores abordados integrando à vivência religiosa, problemas há muito presentes na vida dos moradores (como o caso da Avenida Brasília). Assim como a percepção das transformações no espaço de vizinhança, os moradores pesquisados teceram, em suas falas, uma teia, em que o cotidiano religioso se mistura em uma prática ritualística entre as limitações físicas do espaço e o estranhamento do crescente número de novas segmentações religiosas que se estabeleceram no bairro por meio das novas famílias residentes.

Em nossa conversa com as senhorasF. (82 anos) eN. (61 anos) ${ }^{11}$, ao tocarmos no assunto de suas respectivas identidades religiosas, uma série de elementos

\footnotetext{
${ }^{10}$ Entre as sete ruas do bairro, a Rua Zacarias de Góes se destaca pelo alto número de desempregados e trabalhadores informais ( 9 dos 13 moradores com idade entre 25 e 59 anos) em que 69,23\% dos moradores entre 25 e 59 anos se encontram nessas condições. Esta precariedade por sua vez, está expressa nas casas em madeira que compõem a rua. Em contrapartida, a Rua Visconde de Guarapuava apresenta um maior número de casas de alvenaria e construções recentes, apesar da alta taxa de informalidade e desemprego entre homens e mulheres entre 25 e 59 anos (68\%).

${ }^{11}$ Ao longo do artigo abordamos as posições religiosas dos moradores do bairro a partir de suas próprias falas. Neste sentido, são identificados pelas iniciais de seus nomes no corpo do texto, e iniciais e idade entre parênteses nas citações longas.
} 
acerca das primeiras manifestações religiosas católicas no bairro começaram a se materializar, associando a história da paróquia freqüentada pelos moradores católicos do bairro (Nossa Senhora do Rosário) a sua trajetória de vida.

A dona F. foi a primeira cozinheira do Bispo. A dona B. era a lavadeira do Bispo né? E o Bispo dava aquele monte de revistas para a dona B., $e$ a dona B. me dava: - Fica com isso dai que aquele Bispo parece que é doido, eu não leio, sou lavadeira né? E no meio daquilo tudo. É aqueles livros, aquelas revistas, daqueles livros, tinha uma revista de catequese. É aquelas (Via Gelica Ese Lita) é uma revista do sentimento de Cristo né? Com planejamento de aula, normas pedagógicas, tudo. Eu lia aquilo ali.

Então eu lendo aquilo, foi que...

Que eu tive interesse pra dá catequese. E aquelas revistas me orientaram bastante. Então quando a dona B. chegava lá do Bispo, eu falava: Escuta o Bispo deu mais revistinha pra senhora? Então ela sempre trazia, sempre trazia. E eu lembro né? Que por essas lá, da (Via Gelica Ese Lita) que me ajudou a ensinar catequese. Então tem aquela música que fala: - Fúria feliz e na pena, que não será em vão. Então quer dizer que o Bispo não dava aquilo como...

Ele nunca ia saber que aquilo chegou nas minhas mãos que me tornou uma catequista né?

Material desses. Eu achei tão...

Sempre eu comento com o outro Bispo: - Olha é. Hoje eu não sei né? A importância que a gente. Como um pessoa "faiz" uma coisa confiando em Deus.

Depois vieram as Santas Missões, né? Fez um ranchinho aqui ó [aponta para o terreno que boje é uma pequena metalúrgica em frente a sua residência]. Nessa data, vazia, coberta de capim. E assim tudo começou?

A dona T., as recordações tá tudo na dona T. né?

Passava aqui ó [referindo-se às casas em frente a sua residência]. Era tudo aberto. E corria aqui pra casa de minha tia né?

Que também foi moradora antiga ali.

E daí, a gente começou a fazer umas "fita verde" de Filha de Maria pra não...

A gente começou a ser ... 
A ser Filha de Maria na Vila Nova. Depois que a gente passou pra Nossa Senhora do Rosário. Foi em sessenta e três que ela foi construída.

Dona N. (61 anos)

Observe-se que ao longo da narrativa, a vinda das Missões Dominicanas para a região se associa, em sua cronologia, à autodescoberta da entrevistada enquanto catequista, mantendo sempre próximo de si os elementos que possam legitimar a sua importância dentro do espaço sócio-religioso de sua localidade.

Devemos atentar que na fala de Dona N ela nos remete para um "início" da constituição de um espaço religioso no qual existia uma associação identitária entre os agentes e o espaço. Esta relação com espaço se torna compreensível quando estabelecemos as distâncias percorridas pelos moradores para freqüentarem as cerimônias religiosas. Por não terem, dentro do bairro, sua própria paróquia, os moradores de origem católica do bairro criaram seus vínculos de pertença religiosa com a paróquia localizada no bairro vizinho. Sempre se referindo ao período de sua construção, no qual os moradores participaram, como dizimistas ou por meio de trabalhos prestados à comunidade religiosa.

Aqui nunca teve [se referindo à paróquia dentro do bairro]. Até boje não tem. No Paulista não tem, até hoje não tem.

A paróquia nossa aquié a Nossa Senhora do Rosário, que fica ali no... Na Recreio. Nossa Senhora do Rosário.

Tem que atravessá o asfalto [refere-se à Avenida Brasilia] para ir na Recreio. Na paróquia. Num tem nada aqui. Tem esse grupinho escolar ai embaixo, e mais nada. No Paulista não tem nada. O Paulista é isso aí que você está vendo. Começou assim e assim tá até hoje.

Senhor JC. (80 anos)

Quando perguntamos ao senhor JC acerca da construção da igreja da paróquia Nossa Senhora do Rosário, este prontamente nos respondeu:

Ah, foi os moradores. Os moradores construiu.

Na Vila Nova foi o Benjamim Nalim. Aqui [referindo-se a Vila Recreio] foi aquele padre... esqueci o nome dele... (...)

Participamo também da construção, e até boje. Até boje nóis participa. Até hoje nóis colabora com eles. Nóis tamo lá fazendo lá, agora vai fazer a torre da igreja, já aumentou lá. Pintou os barracão tudo.

Estes fatores de funcionalidade, segurança e solidariedade, mesmo que mediados pela instituição Igreja desenvolveram, nos moradores, este forte 
sentimento de pertença ao espaço, desterritorializando as fronteiras físicas do bairro, tendo na paróquia o valor catalisador de sua identidade religiosa e social. Mesmo percebendo, na fala do senhor JC, a frustração para com o espaço social do bairro, e suas queixas acerca dos obstáculos físicos para ter acesso a sua paróquia (fatores estes que possibilitarão o fortalecimento de uma postura devocional voltada à celebração doméstica, nas Consagrações de Nossa Senhora Aparecida por meio do rádio e da televisão), percebemos, neste entrevistado, um forte sentimento identitário, de pertença ao espaço como seu agente ativo.

\section{A Minha CaSa é a CASA DE MEU SANTo}

Ao falarmos de religiosidade popular, reportamo-nos para os espaços domésticos, abordando, nos elementos cotidianos destas relaç̧ões, as áreas de representações do sagrado no espaço residencial e o processo de relação entre 0 indivíduo (em suas manifestações devocionais), as imagens e a casa.

Numa perspectiva em que o indivíduo constrói, por meio de espaços e imagens, uma área sagrada dentro do espaço doméstico, devemos ter como referência que a imagem não apenas evoca e representa o santo, mas, também, ela o presentifica (MENEZES, 2004). Projetamo-nos então, em um contato devocional que é pautado em um significante imediato e concreto da ação comunicativa (reciprocidade). Nesta relação de reciprocidade, Menezes (2004, p.241) aponta que a "relação de devoção envolve sentimentos, (...) e é marcada pela fé, pela confiança e pela amizade". Um devoto tem fé em seu santo de devoção, ele confia que receberá a sua ajuda, ele o considera um amigo. Como podemos ver neste trecho da fala do senhor JC:

Ab, São José e Nossa Senhora Aparecida. Eu confio neles né? Desde o nascimento, isso já vem vindo de familia né? Já é "dão" (dom) da familia.

Tradição da familia. Já "nascimo" assim.0 meu [refere-se ao nome] é José. São José. Eu venho de São José.

Da devoção dos meus pais. Porque o santo escolbido era São José. Me puseram o nome dele, São José. E da devoção que "nóis" "tinba", "pusemo" o nome do "Zé" R., o nome de São José também. Daí ficou José $R$.

A afirmação "eu confio neles" determina, no entrevistado, uma relação de proximidade muito íntima com o santo, que se reforça por dois vínculos essenciais 
para a construção de sua identidade de devoto. 0 primeiro, quando o próprio diz estar vinculado ao santo desde o nascimento. Nesta relação, o santo se torna um padrinho, estabelecendo um vínculo entre o terreno e o sagrado no cotidiano deste indivíduo. 0 segundo fator, refere-se à tradição familiar. Cultuar o santo é dar prosseguimento às origens, é prestar homenagem à memória de seus familiares, dando seqüência assim, a uma tradição familiar, transformando os seus santos de devoção em uma espécie de patrimônio herdado.

Os santos de devoção são partes integrantes dos grupos familiares, ou seja, tornam-se "membros integrantes" da família na qual são recebidos, construindo com esta, espaços físicos e simbólicos, em uma espécie de reciprocidade associada ao espaço (áreas de demarcação do espaço do sagrado - oratórios, altares e outros) e ao ritmo cotidiano (momentos dedicados a conversação com o santo, rezas, novenas e orações individuais). A criação desse tempo e espaço do sagrado promove uma estreita relação entre o sagrado e o profano, em que o grupo familiar se projeta como o "fiel dignitário" dos interesses do santo, e os espaços do sagrado do ambiente doméstico sacralizam as ações cotidianas.

Sendo este comportamento um padrão comum nos lares de famílias católicas brasileiras, (que não foi diferente nas famílias católicas visitadas), encontramos em seus espaços domésticos vários nichos destinados a receber imagens de santos, sejam elas em estatuetas, quadros ou santinhos. Esses espaços cumprem um papel primordial na execução das preces domésticas, representando, para o indivíduo, a morada do santo em sua residência, o que reserva para este um espaço íntimo de contato devocional, ou seja, garante a possibilidade de uma aproximação entre o devoto e o santo.

\section{DESCREVENDO OS ESPAÇOS DO SAGRADO EM DUAS RESIDÊNCIAS ABORDADAS}

Optamos aqui por uma abordagem descritiva deste convívio (devoto e santo) dentro do cotidiano doméstico de dois entrevistados de nossa pesquisa - o senhor JC (80 anos) e o senhor B (79 anos). Procuramos entender, a partir dos espaços consagrados aos santos de devoção, uma estrutura ritualística que reflita, nesta relação com o sagrado, o caráter humano da devoção. Neste sentido, buscamos observar em suas representações acerca da relação com o santo, como esta pode conduzir a um comportamento social que expande, em um movimento cíclico, uma identidade. Tal identidade pode reforçar os laços de parentesco, por 
meio da perpetuação da ação devocional nos membros das famílias pesquisadas (mediante nomes, culto ao santo, aproximação de grupos que mantém o mesmo perfil devocional); como também esta relação pode ser uma definição de grupo social que encontra, na identidade religiosa e em seus ícones, uma identidade de grupo (grupos paroquiais, grupos de novenas, associações de senhoras etc.).

Em nossas muitas visitas ao senhor JC, percebemos que todos os quartos da residência possuem altares destinados aos santos de devoção. No quarto do casal, encontramos, sobre a cômoda, um pequeno altar improvisado, com a imagem de Nossa Senhora Aparecida e de Santa Edwirges, próximas a uma bíblia aberta e a um copo de água ${ }^{12}$. Enquanto que, no quarto da filha, encontra-se, de frente à porta, um oratório suspenso, ricamente decorado com uma toalha de crochê muito colorida e flores ${ }^{13}$.

Quando procuramos entender, junto à filha do senhor JC, a origem de sua devoção a Nossa Senhora Aparecida, compreendemos que esta se origina na tradição familiar. Em sua infância, a filha do senhor JC foi vitimada pela paralisia infantil e, sua mãe, devota de Nossa Senhora Aparecida, fez uma promessa de levála ao Santuário se esta melhorasse da doença. A promessa foi cumprida quando a filha estava com seus 18 anos, ou seja, os vínculos de devoção foram estreitados por uma ação de graça alcançada (MENEZES, 2004). A devoção nasceu de um voto, uma oferenda, uma promessa feita anteriormente à graça concedida ${ }^{14}$.

\footnotetext{
${ }^{12}$ Ao fazermos as observações acerca dos espaços do sagrado na residência do senhor JC, notamos que esta família sempre preservava, junto às imagens de seus santos, um copo com água. Quando indagamos os familiares sobre o que representava o copo com água próximo às imagens dos santos, os mesmos prontamente responderam ser a água dentro do copo, uma "água benta”, consumida por toda a família como elemento de purificação e cura. De acordo com o senhor JC, esta água é benzida através da Consagração de Nossa Senhora Aparecida, que é transmitida diariamente por uma emissora de rádio, diretamente do Santuário de Nossa Senhora Aparecida.

${ }^{13}$ Neste oratório, encontramos uma estatueta de Nossa Senhora Aparecida que recebera como agrado da filha do senhor JC, um rosário que esta ganhou em uma celebração na paróquia próxima. Acima desta, percebemos um quadro que representa o Santuário de Nossa Senhora Aparecida em Aparecida do Norte - SP, no centro uma imagem de Nossa Senhora do Rosário, padroeira da Paróquia freqüentada pela família. E no lado esquerdo do oratório, existe a presença de uma estatueta da Virgem de Guadalupe e um quadro de Nossa Senhora do Perpétuo Socorro.

${ }^{14}$ Esta relação se mantém por meio de um movimento recíproco de identificação tão intensa, que santo e devoto passam a manter uma relação de proximidade, reforçada por uma ação mistificadora do espaço que deixa de ser parte integrante da casa, tornando-se, assim, morada do santo, e as ações do devoto uma contínua afirmação deste vínculo.
}

OS ESPAÇOS DA FÉ: UM ESTUDO SOBRE O CAMPO RELIGIOSO ... 
No universo de devoção da família do senhor JC, constatamos uma circularidade de bens de salvação que povoam o imaginário da família. Despontam, nestes objetos, um grande número de impressos de divulgação de cultos religiosos, santinhos e impressos que praticamente são manuais de culto ao santo ${ }^{15}$. A circularidade deste material, de acordo com os entrevistados, encontra nas paróquias, seu grande centro de distribuição. Ao consultá-los, constatamos que sua circulação apresenta características distintas: ora têm o valor de ex-votos de graças alcançadas, ora são verdadeiros manuais da prática de culto ao santo para os espaços domésticos. Isto é, os materiais orientam os fiéis em sua prática diária na vida católica, divulgam campanhas de grupos religiosos da paróquia, servem como objeto de comercialização da fé e da identidade de grupo (muitos são vendidos para angariação de fundos). Esta circularidade de bens religiosos transcende ao espaço da paróquia, estende-se ao mercado da mendicância, onde estas orações são comercializadas em espaços públicos com grande fluxo de pessoas $^{16}$.

No comportamento receptivo deste material devocional, percebemos que este possibilita uma ação de reciprocidade entre devoto e santo, em que a presença do segundo torna suportável e segura a existência do primeiro. Reforçam-se, no devoto, suas esperanças diante de situações adversas do cotidiano vivenciado.

Neste tipo de impresso, existe uma orientação doutrinária (visto que estes são distribuídos dentro das paróquias) do comportamento devocional do entrevistado. Seus hábitos religiosos, dentro do espaço doméstico, tornam-se reproduções de um sistema institucional de culto aos santos da Igreja, (mesmo quando não lidos, pois o impresso na ação devocional dos entrevistados, legitima a fé). Trata-se, então, de um ciclo universalizante que se reflete no comportamento paroquial dos fiéis, no qual devoção se mistura ao catecismo, em forma de livros da família, guias de reflexão, programas de televisão orientando a reza de terços, programas de rádio, santinhos, panfletos e impressos. Materiais distribuídos e controlados pela própria diocese.

\footnotetext{
${ }^{15}$ Um panteão de santos povoa a bolsa da filha do senhor JC; santinhos dos santos mais diversos revelam um apego intenso desta às santidades, na tentativa de minimizar seus problemas de saúde, pois como a própria afirma: "Nunca saio de casa desprotegida". Esta busca de proteção transforma qualquer informe religioso em objeto de cultuação; a mesma muitas vezes não os lê (como afirma), recolhe-os em detrimento das ilustrações de seus santos de devoção e as orações nestes contidos.

${ }^{16}$ Porém, direcionamos neste momento nossa abordagem, não para o campo de circulação destes bens simbólicos, mas sim, para o valor significante desses impressos dentro do cotidiano destas famílias.
} 


\section{A CONVERSÃo e A FUNCIONALIDAde da FÉ}

Nas nossas observações sobre a constituição social do bairro, o senhor B (79 anos) surge como um personagem intrigante, ao ser um dos "fundadores" da favela que se formou junto a bairro. Este, dentro do seu universo religioso, apresenta um paradoxismo entre a sua origem católica e sua atual condição de presbiteriano "não-batizado". Nas duas visitas que fizemos à sua residência, não encontramos nenhum espaço consagrado a ser um espaço de oração (pequenos oratórios, mesas para bíblias, etc.), no entanto, encontramos um quadro com a imagem da Virgem Maria e o Menino Jesus. Este quadro passaria despercebido em nossas observações acerca do espaço, se o entrevistado não se declarasse, ao longo da entrevista, como sendo presbiteriano. Cabe notar que o culto a imagens estaria proibido para um presbiteriano rígido. Procurando entender essa ação prática do entrevistado, começamos a observar o processo de sua conversão ao presbiterianismo, acerca do qual ele afirma que:

E eu não tinha um tostão. Só tinha coragem. Aípassaram para a Igreja "Prisbiteriana". E eles não "aceitava" católico lá. Mas eu vou "fala" "procê". Eu disse pra eles:

- Eu não mudo. Porque quando eu nasci, eu já era... Eu nasci com fé em Jesus. E não adianta que eu "tô" com... com... já velho também.

Eu falei:

- Como que eu "vô" ir esse ano que passou para "trais" de Jesus. Quando eu nasci, eu já amei Jesus. Se "ocê" ama Jesus, ele também te ama. Não vou "batiza" não. Eu já sou batizado por Deus.

Então, no meio de todos ali "católico" só ficou eu. A igreja mandou "imbora" tudo. E ai eu fiquei. Fiquei na igreja. Trabalhava. Tomava conta da igreja. A igreja todinha. E saia a noite [eu não enxergava], que eu pousava dentro da igreja. Fechava tudo à igreja, muito grande. E... Trabalhava com fé. E assim fiquei a vida toda ali.

Observe-se que na fala do entrevistado, ele não se refere, em um primeiro momento de sua conversão, à necessidade de uma experiência religiosa, pois quando o mesmo aponta que, “(...) eles não 'aceitava' católico lá.”, ele está se referindo que a Igreja em questão não aceitava, em seu corpo de funcionários, pessoas que fossem externas à comunidade. Isto resultou em uma cobrança por parte da comunidade para que o senhor B se convertesse ao presbiterianismo por meio do batismo, possibilitando assim, que ele se tornasse definitivamente membro integrante da comunidade. 
Ao recusar o batismo, o senhor B estava recusando negar a sua história, sua tradição familiar. Dentro desse movimento de conversão do entrevistado, percebemos que este se manteve dentro da fé professada por sua família: “(...) Quando eu nasci eu já amei Jesus.". A idéia de fé, para um homem cujas experiências o ensinaram a tornar toda situação em uma situação prática, reside na concepção que este faz de seu trabalho, ao longo do tempo em que esteve responsável pela segurança do prédio da igreja. No seu imaginário, ele recebeu do próprio Deus, as benesses de sua situação presente.

\section{"A EVANGELIZAÇÃo DA VILA": A PRESENÇA DA Comunidade AssembléIa de Deus no bairro}

A expressão "evangelização da vila" foi tomada por empréstimo do desabafo de uma católica praticante ao constatar, em sua fala, o crescimento das comunidades pentecostais dentro do bairro. Este dado empírico encontra bases sólidas deste processo transformativo do perfil sócio-religioso brasileiro divulgado pelo censo brasileiro $2000^{17}$.

Em nosso levantamento acerca do perfil sócio-religioso do bairro, constatamos que nos 36 questionários analisados, as comunidades católicas se dividiam entre os freqüentadores da Paróquia Nossa Senhora do Rosário e da Paróquia do Santuário de Nossa Senhora Aparecida e um grande número católicos não praticantes. Enquanto isso, as comunidades evangélicas se distribuíam em várias segmentações e, entre estas, a Igreja Assembléia de Deus foi a que apresentou um maior número de fiéis entre as famílias de moradores abordados (7 dos 12 declarantes $)^{18}$. À vista desta constatação, considera-se como hipótese que

\footnotetext{
${ }^{17} 0$ censo demográfico do Instituto Brasileiro de Geografia e Estatística (IBGE, 2000) publicou números que evidenciam a flagrante queda e perda da secular hegemonia católica - de 91,8\% trinta anos antes, para 73,8\% em 2000 e com estimativa de 65\% para 2010 - e a emergência de inúmeras instituições religiosas e um panteão de miríades celestiais configurando um fenômeno criativo, difuso e contraditório de individuações religiosas (Ver Micro Dados do Censo 2000).

${ }^{18}$ De acordo com dados deste mesmo censo, a Assembléia de Deus dentro do universo religioso pentecostal, corresponde a 47,7\% do total de fiéis, o que, de acordo com Oliva, se deve ao fato de esta proliferar suas casas de oração em bairros empobrecidos e favelas, criando um grande cinturão evangelizador. Este movimento é contrário a outras igrejas pentecostais, que localizam seus templos em áreas mais centralizadas no espaço físico e social do município, como é o caso de Londrina-PR (OLIVA, 2007, p. 149-150).
} 
o fato de existir no Jardim Fortaleza, uma igreja da Assembléia de Deus ${ }^{19}$ seria um fator determinante. Diante desta hipótese, duas questões se levantaram; a primeira questão procura entender se o fato de existir somente esta igreja evangélica dentro do bairro influenciaria na formação de um público evangélico da própria Assembléia de Deus. A segunda questão remete-nos a se a construção da igreja é decorrente das aspirações dos assembleianos da localidade (Jardim Progresso, Jardim Paulista, Jardim Santa Mônica e Jardim Fortaleza).

A estas indagações, tanto o presbítero W (35 anos) quanto o pastor M (53 anos) possibilitaram-nos uma melhor compreensão ao nos contarem a história do início da formação da comunidade da Assembléia de Deus no Jardim Paulista.

Na casa do irmão Laércio né? Foi fundador também. Tudo começou com o irmão "Zé" Braz e, outros irmãos que... outros irmãos que "cooperou" com o trabalho. Os pastores né? Que ajudaram no trabalho evangelístico. Tudo começou pela evangelização né? Do bairro. E os "culto". Né? Que se iniciou na casa da irmã Inês... Aurelinda. Na casa da irmã Aurelinda. E depois já veio da... "alugamo" uma parte debaixo, aqui na rua de baixo, do salão. Na verdade era uma casa né?

Aí depois começou o crescimento da Igreja. Através da evangelização. Tudo graças ao trabalho evangelístico, e Deus foi trazendo ai um reavivamento pro Jardim que até boje, graças a Deus.

Onze anos népastor? [dirige a palavra ao pastor M.]

Onze anos que Deus tem avivado a obra Dele através da salvação e depois dali, "passamo" a outra na esquina né, da... Não me lembro o nome da Rua aqui. Mas no momento mais, ela era uma casa também, e o... O lugar foi pequeno, porque o movimento de gente né? De pessoa. E até que "chegamo" aqui né? (...)

E com o tempo né? Deus tem mostrado o valor de cada irmão. Através do crescimento. Através do crescimento.

Presbítero W (35 anos)

Esta narrativa, acerca do início da comunidade no bairro, nos remete ao ano de 1996, ano em que a comunidade começou a se organizar em torno de alguns núcleos familiares, responsáveis pela organização dos cultos e pela

\footnotetext{
${ }^{19} 0$ Jardim Fortaleza equivale a três quadras residenciais ao lado do Jardim Paulista, ocupando a área próxima do antigo lixão.

OS ESPAÇOS DA FÉ: UM ESTUDO SOBRE O CAMPO RELIGIOSO ... 
"evangelização do espaço" ${ }^{20}$. No desdobrar de nossa conversa, percebemos em ambos os entrevistados, que a construção da identidade da comunidade dentro do bairro se deu por meio daquilo que eles chamam de: "trabalho de evangelização" de novos fiéis. Ao se referirem às atuais condições da comunidade, ambos os entrevistados dão a entender que o crescimento da comunidade dentro do bairro acarretou a ampliação do espaço de culto, que resultou no atual salão da Rua Brigadeiro Franco.

Ao longo de nossa conversa, a palavra "Igreja" se repetia constantemente por meio dos entrevistados. Ao refletirmos esta palavra juntamente com o conjunto de valores expressos em toda a entrevista e no culto, constatamos que a palavra Igreja está associada a um corpo humano dinâmico, ou seja, a Igreja apontada pelos entrevistados é a própria comunidade. Neste sentido, o sentimento de pertença é reforçado por uma ação participativa direta dos membros da comunidade religiosa no processo de formação da comunidade no bairro ${ }^{21}$.

Uma Igreja que se institui pautada nos moldes do cristianismo primitivo, uma comunidade de fé2 2 .

\footnotetext{
${ }^{20} \mathrm{~A}$ expressão "evangelização" é uma forma corrente nas falas dos três entrevistados que representa no sentido prático dos mesmos, 0 ato de levar a Palavra de Deus a os que ainda não a conhecem. Ou seja, através de cultos domésticos, exercícios de leituras bíblicas, entregas de panfletos e abordagens diretas, os membros da comunidade procuram arregimentar mais fiéis para a comunidade, promovendo aquilo que eles chamam de conversão de homem do mundo em cristão.

${ }^{21}$ Ambos se referem constantemente ao trabalho de evangelização. Este trabalho é desenvolvido pelos próprios agentes da comunidade por meio da construção de vínculos de amizade com os moradores do bairro que ora se dá dentro do ambiente de trabalho, ora se dá no espaço de vizinhança ou por abordagem e apresentação da proposta evangelizadora ao estranho, refletem como a "profissão de fé" dos agentes desta comunidade.

22 “(...) A comparação da igreja do século XX com a igreja primitiva, aquela que brilhou nos "Atos dos Apóstolos”, embora distante, sempre será necessária para não se perder o referencial. Alguns fatores que eram simplesmente considerados comuns naquela igreja são, atualmente, mencionados apenas no discurso. Porém, da teoria à prática, o caminho a percorrer tem sido distante. Dentre alguns fatores de destaque desta comparação, podemos citar a admissão de novos membros; 0 amor entre os irmãos, a comunhão e o repartir do pão; a postura e a dedicação dos ministros à oração e jejuns; os contínuos milagres e manifestações dos dons espirituais no dia a dia dos crentes; o critério para a separação dos obreiros para o ministério; o tratamento implacável para com os hereges e o carinho para com os fracos de fé; o cuidado com os novos crentes; o posicionamento do cristão diante da sociedade contemporânea; a liturgia, etc., todavia, se nos aproximarmos um pouco mais para o novo século em que vivemos, surge um novo referencial. Refiro-me ao início das Assembléias de Deus no Brasil" (COSTA, 2005, p.1).
} 
Para entendermos as atividades socializadoras que estabelecem a identidade do grupo por meio da experiência espiritual - daí a denominação "comunidade de fé", procuramos entrar em contato com nossos entrevistados dentro da ação desta experiência religiosa. Para isso, combinamos realizar nossa entrevista logo após o culto, o que nos possibilitaria a visualização de uma experiência coletiva da individualização da fé. Chegamos por volta das 20 h30 no espaço, quando o culto já se havia iniciado uns 20 minutos antes. Em meio a hinos cantados por um pequeno coral de jovens cuja exaltação se direcionava à figura de Jesus Cristo, o restante do grupo, aproximadamente 50 pessoas, entre mulheres, crianças e homens, orava fervorosamente. Era, a nosso ver, um conjunto de orações individualizadas, que ao mesmo tempo se coletivizava em uma experiência socializadora da fé.

Os elementos desencadeadores desta experiência eram os cânticos e as pregações de passagens bíblicas por parte dos presbíteros, que pareciam despertar, nos fiéis, um sentimento de afirmação das "Verdades bíblicas". Tal afirmação se realiza através de um sentido pessoal (como se a passagem bíblica transcendesse o tempo mítico-religioso para o tempo histórico dos agentes) que reforça a sua identidade de homens de fé. As orações promoviam, no espaço, um som altíssimo, ao que se misturavam um conjunto de ações expressivas (corpos se contorcendo, batidas fortes dos pés no chão, muito choro) que parecia remetê-los a um transe espiritual.

Na dinâmica da ação dos agentes, despontaram dois elementos norteadores na construção do sentimento de pertença religiosa. 0 primeiro refere-se à ação de aceitação ou negação da Salvação e o segundo refere-se a uma orientação ética, cujos ensinamentos dos princípios morais têm suas bases enraizadas nas "Verdades Bíblicas".

Tendo estes princípios como pontos de discussão neste momento, cabe-nos discuti-los a partir do conceito de babitus em Bourdieu, enquanto orientador das condutas individuais que possibilita um "acordo" dentro das práticas coletivas do grupo. Ou seja, é por meio do babitus que encontramos na materialização das projeções individuais, o espaço de um imaginário coletivo, em que os agentes sociais trazem inscritos, em seus corpos, sistemas de percepção, apreciação e ação através de suas experiências vivenciadas - na vida de Salvação e da vida no Mundo negada. Isto permite tanto operar atos de reconhecimento prático fundados em uma busca existencial (condicional) e de interesse (convencional), criando, nos agentes, uma predisposição a agirem dentro da comunidade, como "agentes de fé", como podemos notar na fala do presbítero W: 
É, meu caso aí, é quase semelhante, sempre as "conversão" acontecem quase que "parecida" uma com a outra né? O que muda é as "bistória" né?

No caso algumas pessoas "sai" do alcoolismo, outras "sai" das drogas, outra da prostituição. Isso tudo né? Vem assim quase que parecido à mesma bistória, mas só muda o que como a pessoa se envolveu com o mundo.

No meu caso, eu, quando eu aceitei a Cristo como meu Salvador, o meu Libertador, como meu Senhor.

Para servir ao Senhor você tem que conbecer o seu senhorio né?

Então foi quando eu "tava" em uma situação de miséria. Drogado, jogado. A familia né? Quase que eu não tinha contato com minha mãe, com os "irmão". E o meu pai já era falecido. Me envolvi cedo com drogas, com bebidas né? Até com roubos, com pequenos roubos. Mas quando Deus o prove de salvar, Ele entrou com salvação através da minha irmã.

Que a minha irmã também foi uma pessoa alcoólatra que bebia. Que depois que ela aceitou a Cristo veio então a Salvação pro seu lar. Aí logo já veio meu irmão, que tava aqui com a gente, até aqui, acho que foi "trabalha". Mas ele aceitou a fé preso, dentro da cadeia, foi um ato de evangelismo.

Tudo através da evangelização né?

A Bíblia já diz, "A fé vem por ouvir. Por ouvir a Palavra de Deus." E o próprio Jesus diz, "Conhecereis a Verdade e a Verdade os libertará." No caso, libertou a mim, libertou primeiro a minha irmã, libertou a mim, o meu irmão. E já tem vários da minha familia que já "tão" né? Sendo encaminhados também pra Casa de Deus.

$\mathrm{Na}$ fala do presbítero $\mathrm{W}$, encontramos três elementos que despontam nas representações acerca do Mundo no imaginário da comunidade abordada. 0 primeiro é a conversão como uma ação de escolha Divina, como uma relação de "Exemplos". 0 segundo refere-se à vida anterior como uma vida que deve ser abandonada em toda a sua pecaminosidade, para se viver como "servo do Senhor". E o terceiro e último, refere-se à construção de um forte sentimento de pertença que estabelece sentido a esse divisionismo, criando, no assembleiano, uma identidade que o coloca na vivência do material como "homem de fé".

Uma expressão usual entre os agentes, que atesta o seu sentimento de pertença à comunidade religiosa, é o uso contínuo da expressão "irmão". Ao 
longo de nossa pesquisa, procuramos observar como os agentes estabeleciam entre si seus elos de identidade, de pertença tanto ao espaço físico do bairro, quanto às suas "comunidades identitárias". Em nosso primeiro contato com os membros da Igreja Assembléia de Deus, percebemos que o uso contínuo desta expressão promove um estreitamento dos laços dos membros da comunidade, ao mesmo tempo em que reforça nestes a sua identidade enquanto participante de uma comunidade.

Neste sentido, a expressão "irmão", no conjunto desta relação social, exprime a condição dos eleitos, filhos de Deus, portanto, uma comunidade em que seus agentes são responsáveis diretos pela preservação e pelas práticas dos valores doutrinários de sua fé: "irmãos em fê".

Contrariamente ao devocionismo dos católicos consultados no bairro, estes pentecostais acreditam que a cura espiritual está em uma relação direta com Deus, ativada pela ação do Espírito Santo, sem a necessidade de nenhuma intercessão de santos - o que para a comunidade surge como uma forma de idolatria, prevista e condenável pela Bíblia. Este elemento fica evidente, quando observamos, na própria composição física do salão de culto, um grande barracão azul externa e internamente, e que no altar não existe nenhuma imagem. Ou seja, o contato com Deus é direto sem intercessores ou, dito de outro modo, a manifestação do sagrado se dá no espaço por meio da pregação da própria Bíblia e de seus ensinamentos, sendo a manifestação da festa da fé.

Ao pensarmos essas práticas dentro de uma ação dicotômica na relação que católicos e pentecostais estabelecem com o mundo, encontramos que: o sistema comunitário do catolicismo popular transforma todas as situações de rito coletivo em um momento de festa que, historicamente, mistura o sagrado e o profano em um mesmo espaço de ação; enquanto que o pentecostal faz a vida fugir deste "profanismo" católico, fazendo da vida uma festa de fé (BRANDÃO, 1981). Ou seja, estas religiões procuram substituir o cotidiano devocional do catolicismo por tempos e espaços de uma festa permanente. Desse modo, dentro das atividades atribuídas à evangelização, que se transformam em uma prática cotidiana do "crente" fervoroso, a sua maior parcela do tempo é destinada à Igreja. Assim, a Igreja pentecostal o separa do Mundo, com a condição de criar para ele um mundo separado, não só do ponto de vista ético, mas também cultural.

No intuito de transformar o culto em espaços abertos, num ato público de celebração de fé, os agentes pentecostais procuram, por meio deste contato aberto 
com o restante da população do bairro, chamar a atenção da comunidade para este "universo evangelizado", o que possibilita uma prática que constatamos ao longo do culto no salão. Um dos assembleianos tomado de "Graça" convida às pessoas presentes com problemas pessoais em seu cotidiano a receber a Graça do Espírito Santo. A pessoa, seja ela membro da comunidade religiosa ou não, deve encaminhar-se ao centro para que todos orem por ela no intuito de combater 0 mal que a atormenta (seja este o desemprego, crises familiares, problemas afetivos etc.). Tal expansão acaba por incomodar algumas famílias católicas, como o caso de uma moradora que se sente invadida em seu espaço social, com a presença crescente da comunidade evangélica no bairro.

Como vimos, o espaço cotidiano da ação religiosa fragmenta-se em um conjunto de interesses e práticas da fé. Este movimento ora reflete, em suas intenções, uma proximidade nas perspectivas dos agentes (sejam eles católicos ou pentecostais), ora em suas práticas, demarcando a distância dos valores estabelecidos, determinando seus espaços e identidades dentro do espaço social do bairro.

\section{CONSIDERAÇõES FINAIS}

Retomando a indignação da moradora católica ao afirmar que o bairro está passando por um processo de evangelização, esta nos remete a dois quadros em transformação que, em escala macro e micro, dialogam no plano social e religioso destes grupos de moradores. 0 primeiro dado remete ao espaço de vizinhança do Jardim Paulista, apontando para uma coincidência entre o processo de reconfiguração do espaço de vizinhança com a chegada dos novos moradores ao bairro (processo que se desencadeou nos últimos 13 anos de forma mais intensa). 0 segundo remete à intensificação da presença das famílias evangélicas, com a ação mais incisiva dos agentes assembleianos no espaço social, assim como o reconhecimento do enfraquecimento da presença de famílias católicas participativas nos núcleos paroquiais.

Este fenômeno em dados gerais reflete o campo religioso brasileiro revelado pelo Censo de 2000, que mostram que, entre 1991 e 2000, a porcentagem de católicos caiu de 83,3\% para 73,9\%, enquanto que a dos evangélicos cresceu de 9\% para 15,6\% e a dos "sem religião, subiu de 4,7\% para 7,4\%. Diante disso, os católicos em números absolutos correspondem a 125 milhões de pessoas, os evangélicos a 26 milhões, sendo que a somatória gera uma porcentagem de 89,3\%, 
isto é, 151 milhões de fiéis dos 170 milhões de habitantes²3.

De acordo com Antoniazzi (2003, p. 77), as transformações no universo religioso brasileiro contemporâneo estão arraigadas em um sistema de transformação social, econômica e cultural da sociedade brasileira. Para 0 autor, estas transformações neste campo mais amplo que envolve os agentes religiosos, apontam para dois caminhos: a modernização dos hábitos da população brasileira e o crescimento do individualismo e do subjetivismo. As características culturais e sociais revelam, em si, um conjunto de práticas religiosas personalizadas e descentralizadas da própria doutrina religiosa católica. Também colocam em evidência um conjunto plural de crenças e imbricamentos de diversas concepções religiosas tendo em vista a centralidade do ato religioso se transferir para o agente social e não mais na instituição só, dando lugar a um trânsito de indivíduos que vivenciam experiências em outras religiões, sem falar dos que conscientemente praticam mais de uma religião simultaneamente ${ }^{24}$.

Acerca desta transformação do campo religioso brasileiro, encontra-se, nestes dados objetivos, a presença de um perfil identitário católico denominado "catolicismo nominal", sem vínculos ou presença institucional (MARIZ, 2006). Este elemento está presente em nossas observações acerca do campo religioso do Jardim Paulista, assim como também identificamos um catolicismo tradicional, tal qual observamos nos hábitos religiosos do senhor JC, que convive em diálogo constante com o catolicismo romanizado de sua paróquia e dos veículos de comunicação.

Contudo, o que se visualiza nesta pesquisa é uma forte presença de um catolicismo tradicional, movediço em suas bases heterogêneas com um movimento

\footnotetext{
23 " 0 restante do universo, $3,5 \%$, que integram a diversidade religiosa do país equivalem a 6 milhões de pessoas, distribuídas entre: espiritismo kardecista (1,38\%), religiões afro-brasileiras $(0,34 \%)$, budistas $(0,15 \%)$, Seicho-No-Iê, Perfect Liberty, Sinto, Bahai, Messiânica $(0,11 \%)$, esotéricos $(0,04 \%)$, hinduístas $(0,001 \%)$, judaísmo $(0,06 \%)$, islamismo $(0,01 \%)$ e as religiões de tradição indígena, identificadas pelo Censo de 2000, como União Vegetal, Santo Daime, A Barquinha (0,01\%)" (ANTONIAZZI, 2003, p. 74).

${ }^{24}$ De acordo com o referido autor, os dados do Censo 2000 revelam que a religiosidade continua muito alta entre os brasileiros. A declaração "sem religião" parece indicar mais uma "desinstitucionalização" da religião e a emergência da chamada "religião invisível". 0 indivíduo não adere mais a uma religião institucionalizada, mas reduz a religião a um sentimento pessoal, íntimo, não acompanhado pela participação em comunidades ou instituições religiosas. Mas não deixa de rezar (ao menos ocasionalmente) e de acreditar em Deus, quase sempre.
} 
constante entre a doutrina e a tradição religiosa católica brasileira, assim como também, um trânsito entre a experiência individual e a busca de segurança. Isto é, uma identidade coletivizada na fé.

\section{REFERÊNCIAS}

ANTONIAZZI, Pe. Alberto. As Religiões no Brasil segundo o Censo de 2000. REVER - Revista de Estudos da Religião, n. 2, 2003. p. 75-80.

BACZKO, Bronislaw. A Imaginação Social. Enciclopédia EINAUDI. vol. 5. Lisboa: Imprensa Nacional/Casa da Moeda, 1985.

BARROS, Manuel de Souza. Arte, Folclore, Subdesenvolvimento. Rio de Janeiro: Civilização Brasileira, 1970.

BOURDIEU, Pierre. Gênese e Estrutura do Campo Religioso. In: A Economia das Trocas Simbólicas. São Paulo: Perspectiva, 2005.

. Apêndice I: Uma Interpretação da Teoria da Religião de Max Weber. In: A Economia das Trocas Simbólicas. São Paulo: Perspectiva, 2005.

BRANDÃO, Carlos Rodrigues. Sacerdotes de viola: Os Rituais Religiosos do Catolicismo Popular em São Paulo e em Minas Gerais. Petrópolis: Vozes, 1981.

. Memórias do Sagrado: estudos de religião e ritual. São Paulo: Paulinas, 1985.

CESAR, Waldo. 0 que é "Popular" no Catolicismo Popular. Revista Eclesiástica Brasileira, vol. 36, fascículo 141, março de 1976.

CHARTIER, Roger. "Cultura Popular": revisitando um conceito historiográfico. Estudos Históricos, vol. 8, n. 16.. Rio de Janeiro, 1995.

COSTA, José W. Bezerra da. Nossa Identidade - Diretrizes da Doutrina da Assembléia de Deus. Disponível em: www.assembleiadedeus.org/nossa_identidade. htm [acesso em 23 de março de 2007].

IBGE. Diversidades: retratos das religiões no Brasil. Micro-dados censo 2000. Disponível em: www.fgv.br/cps

DURKHEIM, Emile. Sociologia. São Paulo: Ática, 1988.

ELIADE, Mircea. O Sagrado e o Profano: a Essência das Religiões. São Paulo: Martins Fontes, 2001. 
MARIZ, Cecília Loreto. Catolicismo no Brasil contemporâneo: reavivamento e diversidade. In: TEIXEIRA, Faustino; MENEZES, Renata (orgs.). As religiões no Brasil: continuidades e rupturas. Petrópolis: Vozes, 2006.

MARTELLI, Stefano. A Religião na Sociedade Pós-Moderna. São Paulo: Paulinas, 1995.

MENEZES, Renata de Castro. A Dinâmica do Sagrado: Rituais, Sociabilidade e Santidade num Convento do Rio de Janeiro. Rio de Janeiro: Relume Dumará/ NuAP, 2004.

OLIVA, Alfredo dos Santos. A História do Diabo no Brasil. São Paulo: Fonte Editorial, 2007.

PAIM, Antonio; PROTA, Leonardo \& VÉLEZ RODRÍGUES, Ricardo. Aproximação Transcendental a Vivência Religiosa. In: Religião. Londrina: Eduel, 1997.

SANCHIS, Pierre. Problemas na análise do campo religioso contemporâneo. In: MARIN, José Roberto (org.). Religiões, religiosidades e diferenças culturais. Campo Grande: UCDB editora, 2005.

VOVELLE, Michel. Ideologias e Mentalidades. São Paulo: Brasiliense, 1985.

WEBER, Max. Sociologia de la Religion. 1999. http://www.4shared.com/ file/34461679/b5472387/max_weber_-_sociologia_de_la_religion.html?s=1 [acesso em 15 de agosto de 2007].

WOODWARD, Kathryn. Identidade e diferença: uma introdução teórica e conceitual. In: SILVA, Tomaz Tadeu (org). Identidade e diferença: A perspectiva dos Estudos Culturais. Petrópolis: Vozes, 2000. 